\title{
FILM BAGURAU; REPRESENTASI CITRA PEREMPUAN MINANGKABAU
}

\author{
Yuditia Leo Andhika \\ Mahasiswa Program Studi S-2 Penciptaan dan Pengkajian Seni \\ Minat Studi Penciptaan Film \\ Institut Seni Indonesia (ISI) Surakarta \\ J1. Ki Hadjar Dewantara no. 19, Surakarta 57126 Jawa Tengah \\ yudileobbbbb@gmail.com
}

\begin{abstract}
ABSTRAK
Bagurau adalah film pendek yang mengangkat isu perempuan Minangkabau saat ini dalam menanggapi perubahan kehidupan sosial masyarakat. Film ini lebih memfokuskan cerita pada fenomena perempuan Minangkabau dari sudut pandang Tukang Dendang dalam suatu pertunjukan musik malam Bagurau. Masyarakat Minangkabau masih menganggap bahwa menjadi Tukang Dendang adalah pekerjaan yang tidak sesuai norma agama dan adat yang dipegang oleh masyarakat Minangkabau. Limpapeh rumah nan gadang yaitu istilah bagi perempuan Minangkabau berarti perempuan bijaksana yang merupakan tiang penyangga dari keutuhan rumah, menjadi pedoman, memiliki budi pekerti yang baik, taat pada norma agama dan adat. Pedoman tersebut luntur bagi perempuan Minangkabau yang berprofesi sebagai Tukang Dendang. Film ini menghadirkan citra perempuan Minangkabau yang memiliki sudut pandang tersendiri dalam adat budayanya.
\end{abstract}

Kata kunci: Bagurau, Masyarakat Minangkabau.

\begin{abstract}
Bagurau is a short film that adopts the issue of today Minangkabau woman in responding the change of people's social life. This film focuses its story more in the phenomenon of Minangkabau woman from tukang dendang's (singer's) point of view in a music performance of Malam Bagurau. Minangkabau people still considers that tukang dendang (singer) is an occupation that's not in accordance with religious and customary norms hold by Minangkabau people. Limpapeh rumah nan gadang is the term for Minangkabau woman meaning wise woman that is the pillar of house integrity, becomes role model, has good characters, and obeys the religious and customary norms. For Minangkabau woman whose profession is tukang dendang (singer), that role model is faded. This film present Minangkabau woman's image that has her own point of view in her custom and culture.
\end{abstract} Keywords: Bagurau, Minangkabau people 


\section{Yuditia Leo Andhika}

\section{PENDAHULUAN}

Minangkabau merupakan salah satu daerah kebudayaan etnis dari banyaknya etnis yang ada di Indonesia. Dalam pandangan kebudayaan Minangkabau, wilayah Minangkabau terdiri dari dua wilayah utama, yaitu wilayah pusat dan pinggiran. Daerah pusat dinamakan luhak dan daerah pinggiran dinamakan rantau. Luhak adalah daerah pedalaman Minangkabau yang terletak di dataran tinggi di sekitar pegunungan, yakni Gunung Merapi, Gunung Singgalang, dan Gunung Sago. Daerah inilah yang dianggap sebagai pusat alam Minangkabau atau sering juga disebut Luhak Nan Tigo (Tiga Daerah), yakni Luhak Tanah Datar, Luhak Agam, dan Luhak Limapuluh Kota. Sedangkan daerah rantau berada di sekeliling daerah asli yang lahir kemudian akibat berkembangnya umat manusia. Dari daerah asal mereka mencari daerah baru untuk mengembangkan diri yang disebut rantau tersebut.

Dalam wilayah budaya Minangkabau, perempuan memiliki posisi dan kedudukan sosial yang sangat penting, selain sebagai penerus garis keturunan, juga merupakan figur yang sangat menentukan dalam kehidupan moral dan martabat sebuah keluarga atau kaum. Secara harfiah perempuan di Minangkabau diidentikan dengan Bundo Kanduang yang bisa diartikan sebagai "Ibu Sejati" (Hakimy,
1994: 41), diibaratkan sebagai Limpapeh Rumah nan Gadang (tiang utama rumah gadang). Bundo Kanduang dalam pengertian fungsinya mengacu kepada perempuan senior atau ibu utama dalam suatu keluarga matrilineal Minangkabau. Sistem matrilineal adalah keturunan dan harga benda-benda diperhitungkan melalui garis keturunan ibu dan bukan garis bapak, sehingga yang berkuasa atas seluruh kelompok keluarga adalah saudara laki-laki seorang istri dan bukan suaminya. Sistem ini telah memberi kehormatan dan keberuntungan terhadap kehidupan perempuan Minangkabau. Dikatakan demikian karena sistem matrilineal tersebut memberi perlindungan terhadap perempuan Minangkabau dari segi moril maupun materil.

Dari segi moril perempuan Minangkabau terlindungi dan memiliki derajat lebih tinggi, karena dalam budaya Minangkabau laki-laki persukuannya bertanggung jawab mengontrol sikap dan tingkah laku kemenakan atau saudara perempuannya. Hal ini dilakukan agar para perempuan Minangkabau tidak menyalahi norma agama dan norma adat yang digunakan sebagai pegangan hidup. Apabila perempuan Minangkabau bermoralitas buruk, maka seluruh keluarga persukuan laki-laki maupun perempuan akan merasa malu dan hina hingga menyebabkan jatuhnya martabat atau harga diri sebagai 
perempuan Minangkabau. Dari segi materil kedudukan perempuan Minangkabau juga terlihat terlindungi, segala hasil harta pusaka keluarga seperti tanah dan barangbarang berharga lainnya diperuntukkan kepadanya (Navis. 1985: 20). Maka merekapun tidak dituntut untuk terlalu bersusah payah mengumpulkan materi guna memenuhi kebutuhan hidup sehari-hari, sebab ia akan bisa hidup baik dan tentram dengan hasil harta pusaka yang diolah dan digarap oleh laki-laki keluarga persukuannya.

Bagi masyarakat Minangkabau, perempuan adalah limpapeh rumah nan gadang. Istilah ini mengandung makna perempuan bijaksana yang merupakan tiang penyangga dari keutuhan rumah, menjadi pedoman, memiliki budi pekerti yang baik, taat pada norma agama dan adat. Akan tetapi martabat perempuan Minangkabau yang selama ini berpedoman kepada limpapeh rumah nan gadang dalam sistem matrilineal luntur pada perempuan yang berprofesi sebagai Tukang Dendang dalam pertunjukan Bagurau. Dikatakan demikian karena kebiasaan dan sikap kehidupan yang dipandang ideal bagi masyarakat Minangkabau harus berpegangan dengan falsafah Minangkabau adat basandi syarak, syarak basandi kitabullah yang artinya adat Minangkabau bersendikan agama, sementara agama bersendikan Kitab Allah, yakni Al-Qur'an. Tukang Dendang dianggap tidak menjaga falsafah tersebut dengan melakukan pekerjaan yang tidak sesuai norma agama dan adat yang dipegang oleh masyarakat Minangkabau. Mereka ke luar larut malam, berkumpul Hal| 58 bersama laki-laki di malam hari, mengumpulkan materi untuk kebutuhan kehidupan, dan lain sebagainya. Dalam wawancara Noni Sukmawati dengan Asmaniar (74 tahun) dalam Tesis S2 Universitar Gadjah Mada "Perempuan Dalam Seni Pertunjukan Bagurau, Perubahan Sosial di Minangkabau" mengungkapkan "Bagurau ko adolah dunia laki-laki, di nagari ko adaik jo agamo malarang padusi kalua malam, dek buruak candonyo. Kalau ado padusi nan kalua malam dikecekkan padusi jalang” (Bagurau adalah dunia laki-laki, di kampung ini adat dan agama melarang perempuan ke luar malam, karena tidak baik kelihatannya. Kalau ada perempuan yang ke luar malam akan dikatakan perempuan nakal).

Bagurau merupakan sebuah pertunjukan musik Saluang dan Dendang yang dipadukan dengan kekuatan sastra lisan Minangkabau melalui pantun-pantun penuh dengan ibarat dan kiasan. Para pemain pertunjukan Bagurau terdiri dari satu orang Tukang Saluang (laki-laki) dan dua sampai empat orang Tukang Dendang (perempuan) serta ada beberapa pertunjukan yang menambahkan instrumen rabab dan orgen tunggal. 
Pertunjukan Bagurau sering diadakan pada kegiatan masyarakat di antaranya seperti pesta perkawinan, sunat rasul, dan batagak penghulu. Tetapi sekarang ini pertunjukan Bagurau dipentaskan tidak selalu mengharapkan pada kegiatan masyarakat, mereka juga melakukan pementasan Bagurau Lapiak. Bagurau Lapiak adalah sebuah bentuk perjuangan para seniman Bagurau dalam mencari nafkah dengan mementaskannya di emperan-emperan toko setelah toko tersebut tutup pada malam hari menggunakan lapiak (tikar). Dalam pertunjukan itu tidak ada aturan tertentu yang mengikat, karena tujuan utamanya untuk hiburan semata.

Sebagai ajang pergurauan, Tukang Dendang Bagurau Lapiak tersebut akan melayani permintaan penonton untuk mendendangkan topik-topik pilihan, dengan menyerahkan sejumlah uang dan memesan dendang yang diinginkan kepada seorang Janang (pembawa acara). Keberhasilan pertunjukan amat ditentukan oleh seorang Janang untuk menghidupkan dan membangun suasana dalam pertunjukan. Topik-topik pesanan yang disampaikan melalui pantun yang dituliskan melalui secarik kertas oleh penonton melalui seorang Janang, biasanya seputar nostalgia masa lalu, cerita-cerita romantis atau sindiran terhadap kelompok-kelompok tertentu dan persoalan-persoalan yang terkait dengan tema perempuan.

Bagurau Lapiak yang memposisikan diri para pelakunya sebagai masyarakat kelas menengah ke bawah membuat pertunjukan ini harus selalu dipentaskan dengan memanfaatkan ruang-ruang yang ada. Konsep hiburan yang meliputi pertunjukan ini akhirnya membuat posisi Tukang Dendang harus memiliki nilai jual yang bagus. Hal ini dikarenakan daya tarik utama Bagurau Lapiak terletak pada perempuan yang menjadi Tukang Dendang.

Keadaan ini akhirnya mengharuskan Tukang Dendang ke luar dari kemapanan adat yang dipegangnya. Ke luar malam, berkumpul dengan laki-laki, mencari nafkah menjadi suatu rutinitas yang harus dilakukannya pada setiap kesempatan pertunjukan yang dilakoninya. Pada dasarnya semua itu dilatarbelakangi oleh keadaan ekonomi. Mereka berjuang mempertahankan keluarga, rumah, dan hidupnya melalui dendang yang dipentasan setiap malam dihadapan banyak laki-laki.

Kegiatan yang mereka lakoni, bagi sebagian masyarakat Minangkabau sangat tidak relevan dengan adat yang dipegang. Kebenarannya terlihat pada Tukang Dendang yang identik dengan memakai pamanih (jimat) sebagai daya tarik para laki-laki yang tidak jarang sudah berstatus suami orang mengalami jatuh cinta kepada mereka. Selain penggunaan jimat dan 


\section{Yuditia Leo Andhika}

penampilan, sindiran pantun-pantun yang didendangkan menjadi salah satu daya tarik yang dimiliki Tukang Dendang.

Dalam konteks perempuan Minangkabau konsep limpapeh rumah nan gadang ini tidak berlaku bagi paraTukang Dendang. Dilihat dari sudut pandang pekerjaan yang mereka lakukan untuk menjaga keberlangsungan hidup. Limpapeh rumah nan gadang memiliki arti yang sangat kuat dalam kehidupan perempuan Minangkabau yaitu sebagai penjaga Rumah Gadang atau Tiang Rumah Gadang.

Pengkarya menafsirkan menjaga atau sebagai Tiang Rumah Gadang ini sebagai sebuah perjuangan yang harus dilakukan oleh perempuan Minangkabau untuk menjaga kelangsungan hidupnya, keluarganya, hingga keturunannya kelak. Konsep berjuang dengan cara menjaga dan menjadi tiang terlihat dalam rutinitas yang dilakukan oleh perempuan yang menjadi Tukang Dendang, adat yang dijunjung oleh mereka sedikit dikesampingkan demi keberlangsungan hidupnya.

\section{Tukang Dendang merelakan} hidupnya dikonotasikan negatif, padahal hanya dengan cara menjadi Tukang Dendang lah dia mampu menjadi limpapeh rumah nan gadang dalam sistem kekerabatan matrilineal.

Pada dasarnya, perempuan sebenarnya dapat menentukan bagaimana dirinya meski budaya telah menentukannya lebih dahulu. Hal ini erat kaitannya dengan citra. Citra dijelaskan oleh Dan Nimmo, segala sesuatu yang telah dipelajari seseorang, yang relevan dengan situasi dan dengan tindakan yang bisa terjadi Hal| 60 didalamnya. Ke dalam citra tercakup seluruh pengetahuan seseorang, baik benar ataupun keliru, semua preferensi yang melekat kepada tahap tertentu peristiwa yang menarik atau menolak orang tersebut dalam situasi itu, dan semua pengharapan yang dimiliki orang tentang apa yang mungkin terjadi jika ia berperilaku dengan cara yang berganti-ganti terhadap objek di dalam situasi itu. Ringkasnya, citra adalah kecendrungan yang tersusun dari pikiran, perasaan, dan keinginan. Citra selalu berubah seiring dengan berubahnya pengalaman.

Citra perempuan dalam film dibentuk oleh ide cerita dan penulis naskah, maka dari fenomena yang dapat diamati pada kehadiran perempuan dalam pertunjukan Bagurau memunculkan polemik yang menarik untuk dijadikan cerita untuk sebuah film.Skenario film Bagurau berangkat dari isu perempuan Minangkabau dari persepktif Tukang Dendang dalam pertunjukan Bagurau di Minangkabau.Film ini mengisahkan tentang masalah isu perempuan Minangkabau sebagai Tukang Dendang yang dilihat secara adat dan agama, dan penyimpanganpenyimpangan yang terjadi akibat 
kebutuhan hidup, perubahan-perubahan dan perkembangan kehidupan saat ini. Latar budaya ini menjadi dasar pemikiran dalam menghadirkan karya ini.

\section{PEMBAHASAN}

Terlebih dahulu akan dipaparkan sinopsis dari film Bagurau, berikut ini sinopsisnya:

Dea (35 tahun) seorang janda muda yang berprofesi sebagai Tukang Dendang dalam sebuah kelompok Bagurau di Kota Payakumbuh, Sumatera Barat. Anak tunggal dari keluarga sederhana, mempunyai orang tua yang telah meninggal dunia. Dea tinggal seorang diri disebuah kontrakan, tidak memiliki dunsanak (sepupu) dari garis keturunan ibu maupun ayahnya, Dea adalah keturunan terakhir dari persukuannya dalam satu lingkup keluarga ibunya.

Dea menjalani hari-harinya menjadi Tukang Dendang, melewati beberapa polemik yang bervariasi. Norma adat budaya, sosial, maupun personal menjadi beban bagi Dea dalam menyikapi realitas kehidupan yang dijalaninya sejauh ini. Dea ingin hidup bahagia, memiliki keluarga dan bisa memberikan keturunan agar silsilah keluarganya tidak terputus sehingga mencapai derajat perempuan Minangkabau sebagai Limpapeh Rumah Nan Gadang. Ini adalah paradoks atas fenomena perempuan Minangkabau dewasa ini.

\section{Deskripsi Sajian}

Skenario film pendek Bagurau Hal| 61 berjumlah 30 scene dengan pembabakan dibagi menjadi tiga:

\section{Babak I}

Bagian pertama pada film ini terdiri dari 5 scene. Dimulai dari gambaran suasana dan bentuk pertunjukan Bagurau dengan menghadirkan konflik awal di mana tokoh pria utama (Buyung) terlibat perseteruan dengan seorang penonton (Toni) dalam memesan sebuah dendang kepada tokoh utama wanita (Dea). Konflik awal dimunculkan untuk menghadirkan dramatik cerita untuk mendukung alur pada adegan selanjutnya.
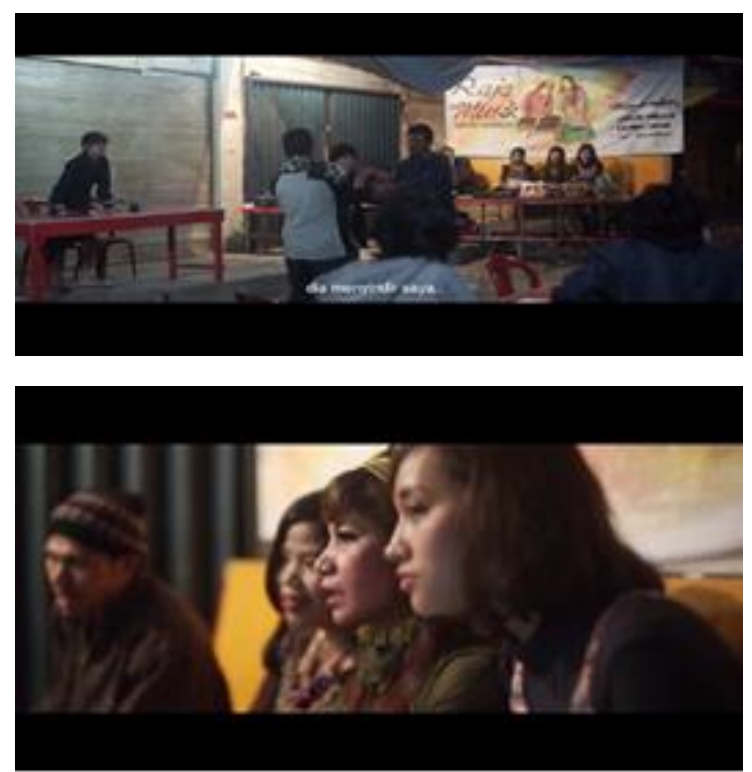

Gambar 1. Scene 1 (Screenshot Film Bagurau) 
Scene 2 memperlihatkan kehidupan sosial Dea dengan masyarakat lingkungan tempat tinggalnya. Kemudian pada scene ini juga menjelaskan kepribadian Dea yang ingin menjadi seorang limpapeh rumah nan gadang dengan menolak tawaran Buyung yang tiba-tiba mengajak menikah. Ini menjelaskan bahwa seorang perempuan Tukang dendang juga memiliki sebuah harkat dan martabat yang masih dijaga.
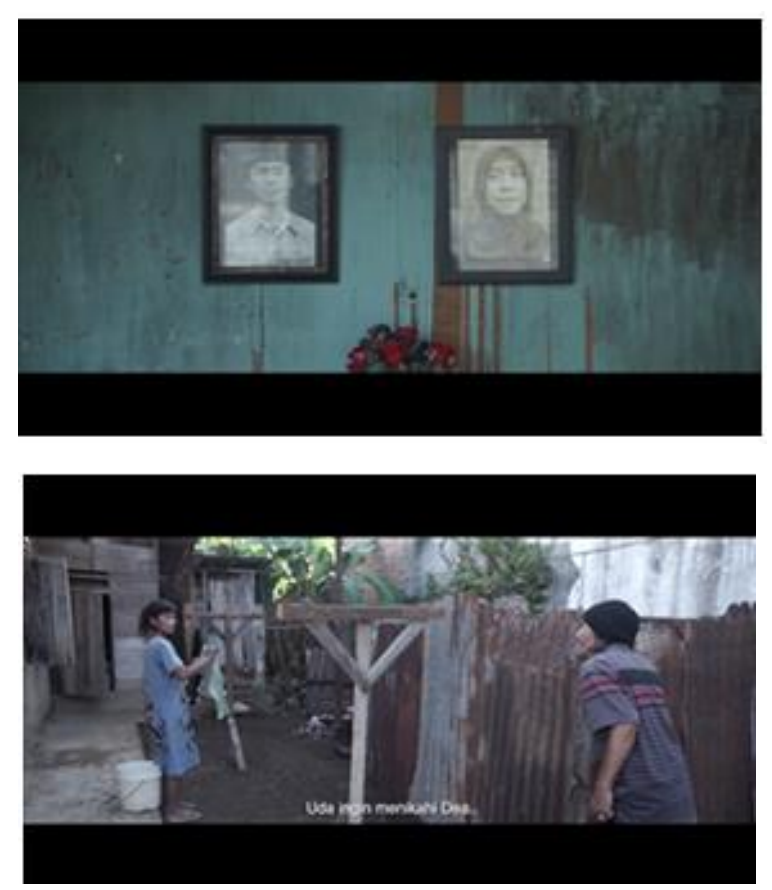

Gambar 2. Scene 2

(Screenshot Film Bagurau)

Pada scene 3 dan 4 memperlihatkan kesendirian Dea menjalani rutinitasnya. Dalam scene ini juga menghadirkan simbol yang menggambarkan sebuah motifasi Dea untuk memiliki sebuah keluarga dengan shotranji keturunannya.

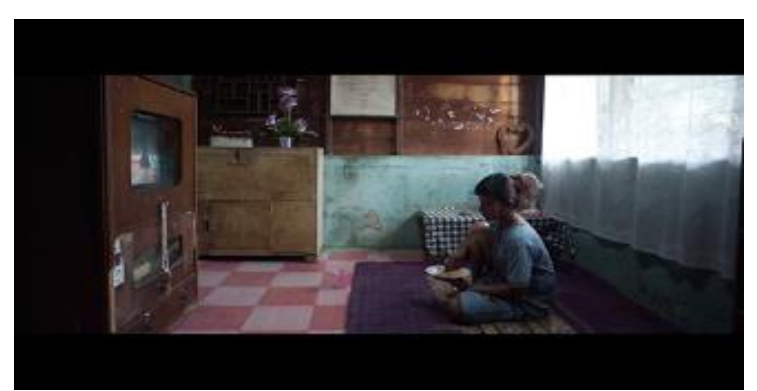

Gambar 3. Scene 3 - 4

(Screenshot Film Bagurau)

Scene 5 menjelaskan identitas orang tua Dea yang sudah meninggal dengan shot foto bapak dan ibunya terpajang di dinding. Scene ini juga memperlihatkan karakter seorang perempuan Tukang Dendang yang merokok dan mengikuti perkembangan zaman dengan teknologi sekarang ini. Babak I ini bertujuan menyajikan gambaran dari karakter tokoh Dea dengan lingkungan kerja, masyarakat dan aktifitas kesehariannya.

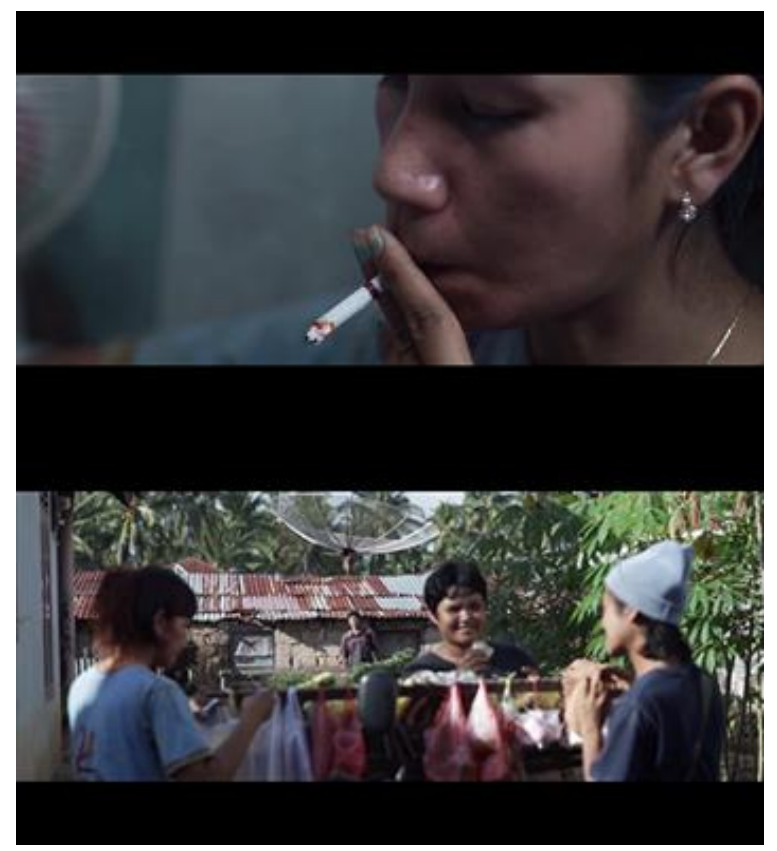

Gambar 4. Scene 5

(Screenshot Film Bagurau) 
1. EXT. PASAR. MALAM. H-1 CAST. DEA, SAMSIR, RANI, HARDI, MIRDA, BUYUANG, ADI, TONI, TEMAN TONI 1, TEMAN TONI 2

MALAM HARI DI SUDUT PASAR KOTA PAYAKUMBUH SEDANG BERLANGSUNG SEBUAH ACARA BAGURAU YANG DISELENGGARAKAN OLEH SEBUAH KELOMPOK BAGURAU. JANANG YANG BERTINDAK SEBAGAI PEMBAWA ACARA MEMBUAT BERLANGSUNYA ACARA MENJADI MERIAH, MEMACU SEMANGAT TUKANG SALUANG (HARDI) DAN PEMAIN ORGEN (SAMSIR) MEMAINKAN INSTRUMEN MUSIK MEREKA. DEA SEBAGAI TUKANG DENDANG YANG MENJADI PUSAT PERHATIAN MELANTUNKAN DENDANG PESANAN PENONTON SECARA MERDU DENGAN PANTUN-PANTUN YANG MEMBUAT PENONTON TERTAWA DAN TERHIBUR. MIRDA MEMBAWA SECANGKIR KOPI UNTUK HARDI YANG ADALAH SUAMINYA KE ATAS PENTAS, SEDANGKAN RANI YANG JUGA SEORANG TUKANG DENDANG SEDANG SIBUK MEMAINKAN HANDPHONE SAMBIL MENGHISAP SEBATANG ROKOK. DISISI KANAN DEPAN PENTAS TAMPAK SEORANG PENONTON (BUYUANG) YANG TERUS MEMPERHATIKAN DEA SEMBARI TERSENYUM. DIMEJA SEBELAHNYA ADA TONI DAN DUA ORANG TEMANNYA MENIKMATI ACARA SAMBIL TERTAWA. DIMEJA PALING BELAKANG ADI DUDUK SENDIRI MENIKMATI ACARA.

JANANG

"SALAMAIK BAGURAU SAMALAM SUNTUAK, KA BAKEH MAMAK SARATO NAN LAI HADIR MALAM NAN KO, KOK KETEK NDAK BASABUIKKAN NAMO, KOK GADANG NDAK DISABUIKKAN GALA. BUYUANG BERJALAN KE PENTAS MEMESAN SEBUAH DENDANG MELALUI JANANG.

(FADE IN INSTRUMEN SALUANG) IKO ADO PASAN DARI UDA BUYUANG UNTUAK DEA, "BEKO SAMO SIA DEA PULANG? BIA LAH UDA BUYUANG NAN MAANTAAN..BULIAH NDAK TARASO DINGIN MALAM NAN KO"

AAA.. BAANYO DEA..? SAMPAIAANLAH KA UDA BUYUANG TU.."

SEMUA PENONTON TERTAWA MENDENGAR PESANAN BUYUANG YANG DISAMPAIKAN OLEH JANANG. DEA
YANG MENDENGAR PESANAN BUYUANG TERSENYUM KECIL DAN MENDENDANGKAN SEBUAH PANTUN UNTUK MENJAWAB PERTANYAAN DARI UDA BUYUANG.

$$
\begin{gathered}
\text { DEA } \\
\text { (DENDANG) }
\end{gathered}
$$$$
\text { Hal| } 63
$$

"RAMILAH PASA DI RAO-RAO, RAMI DEK ANAK MUDO-MUDO, NIAIK UDA ALUN BISA DENAI TARIMO, KARANO DENAI SAURANG JANDO.."

PENONTON YANG MENYAKSIKAN TERTAWA MENDENGAR PANTUN YANG DIDENDANGKAN DEA, BUYUANG TERDIAM LALU MEMPERHATIKAN TONI BERJALAN MENUJU PENTAS MENARUH UANG DAN MEMESAN DENDANG LANGSUNG KEPADA DEA YANG DUDUK DIATAS PENTAS.

EKSPRESI DEA SEIDKIT BERUBAH SETELAH MENDENGAR PESANAN TONI YANG DIBISIKKAN KE TELINGANYA. TONI KEMBALI BERJALAN MENUJU MEJANYA. BUYUANG MEMPERHATIKAN TONI DENGAN WAJAH SINIS.

\section{JANANG}

"LAGU DIPAPANJANG DEK UDA TONI..

LANGSUANG SE LAH DEA..APO BANA NAN DIBISIAKKAN UDA TONI TADI TU.."

SAMSIR DAN HARDI MULAI MEMAINKAN ISTRUMEN MUSIK MEREKA, SEDANGKAN DEA TAMPAK BERFIKIR MENYUSUN KALIMAT PANTUNNYA DENGAN GERAKAN MULUT YANG TIDAK MENGELUARKAN SUARA. DEA

(DENDANG)

“..PAI SANJO PULANG PAGI, ABIH HARI

DILAPIAK GURAU, LAH LUPO ANAK JO BINI, ANAK DENDANG JUO NAN BASILAU.."

BUYUANG MELIHAT GERAM KEARAH TONI DAN HENDAK MENGHAMPIRINYA, JANANG LANGSUNG MEMEGANG BUYUANG. ADU MULUT TERJADI ANTARA BUYUANG DAN TONI MEREKA DIKERUMUNI OLEH PENONTON YANG LAIN. ADI MENYAKSIKAN KERIBUTAN DARI JAUH.

FADE OUT

FADE IN 
2. EXT. PEKARANGAN RUMAH DEA. PAGI. $\underline{\mathrm{H}-2}$ CAST. BUYUNG, DEA, IBU 1, IBU 2, PEDAGANG,

BUYUNG BERJALAN TERBURU-BURU MENUJU RUMAH DEA. DEA KELUAR DARI DALAM RUMAH MEMBAWA SEBUAH EMBER JEMURAN. MELIHAT ADANYA PEDAGANG GEROBAK, DEA MENARUH CUCIANNYA DAN BERJALAN MENUJU KE PEDAGANG TERSEBUT. DI SANA ADA IBU-IBU SEKITAR RUMAHNYA YANG JUGA BERBELANJA. BUYUNG MEMPERHATIKAN DEA DARI JAUH, DEA TERLIHAT AKRAB DENGAN IBU-IBU TERSEBUT. DEA KEMBALI BERJALAN KE DALAM PEKARANGAN RUMAHNYA.

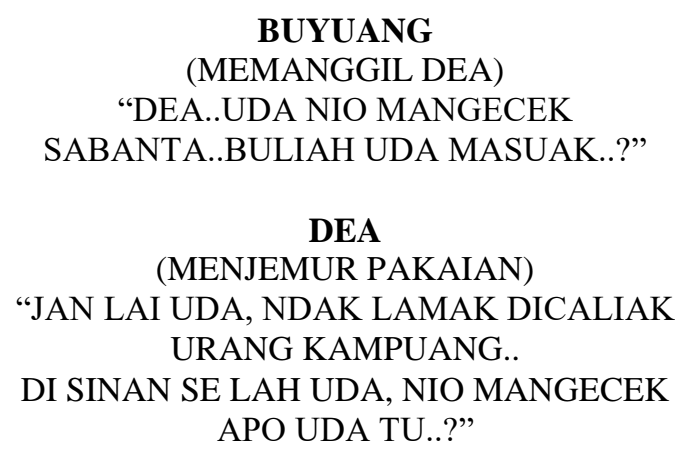

BUYUANG BERDIRI DIBALIK PAGAR RUMAH DEA

\section{BUYUNG}

"DEA.. BARALEK WAK LAH.."

\section{DEA}

"LAI SIHAIK DA?

"NDAK SAMURAH TU SE BARALEK TU

DOH DA, BANYAK LO NAN HARUS

DIPIKIAAN DULU MAH..APOLAI UDA LAH PUNYO BINI LO.."

\section{BUYUNG}

"UDA BISA NGECEK KA BINI UDA.. TAPI..KALAU DEA NDAK NIO, BIA UDA CARAIAN BINI UDA.."

DEA

"SAMURAH TU UDA MANINGGAAN BINI UDA KINI, BISUAK SAMURAH TU LO AMBO UDA TINGGAAN MAH.." (SELESAI MENJEMUR PAKAIAN) "PIKIA BANA LAH ELOK-ELOK DULU DIH DA..AMBO LAH PANEK JO GUNJIANGAN URANG KAMPUANG..AMBO NIO IDUIK TANANG SE NYO.."

\section{BUYUNG}

“APO DEA NDAK NIO PUNYO KELUARGA? ADO KETURUNAN?.."

DEA (BERHENTI BERJALAN) "AMBO ANAK DENDANG, NIO MANJADI LIMPAPEH RUMAH NAN GADANG, AMBO SADANG BAUSAHO UNTUAK ITU DA.."

DEA BERJALAN KE DALAM RUMAH, SEDANGKAN BUYUANG TERMENUNG DI BALIK PEKARANGAN RUMAH DEA.

3. INT. DAPUR. PAGI. H-2

\section{CAST. DEA}

DEA SEDANG MEMASAK DIDAPUR.

4. INT. RUANG TV. SIANG. H-2 CAST. DEA

DEA SEDANG MAKAN SAMBIL MENONTON TELEVISI, TERDENGAR SUARA ADZAN, DEA MEMATIKAN TELEVISI DAN BERJALAN KEARAH DAPUR. TAMPAK DIDINDING RUANG TERSEBUT SEBUAH RANJI KETURUNAN KELUARGA DEA. NAMA DEA TERLETAK DIBAGIAN PALING BAWAH.

5. INT. RUANG TAMU. SIANG. H-2 CAST. DEA

DI DINDING RUANG TENGAH TAMPAK FOTO KEDUA ORANG TUA DEA YANG BERTULISKAN TANGGAL LAHIR DAN WAFAT. DEA SEDANG DUDUK DIKURSI MENGHISAP ROKOK SAMBIL MEMAINKAN HANDPHONE.

\section{Babak II}

Bagian kedua merupakan bagian paling panjang dalam sebuah film, karena konflik yang dibangun pada bagian pertama sudah mulai terlihat. Babak kedua dimulai dari scene 6-25. Bagian ini diawali gambar sebuah kamar mandi di mana Dea akan memulai aktifitasnya bekerja. 


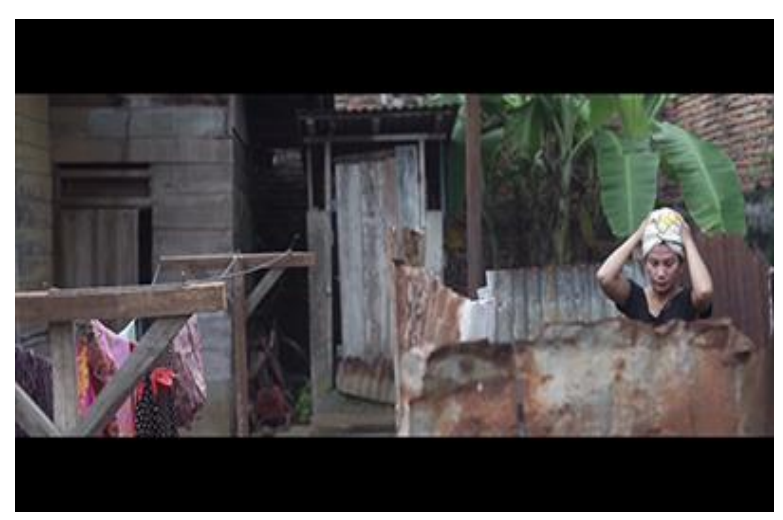

Gambar 5. Scene 6

(Screenshot Film Bagurau)

Kemudian dilanjutkan dengan suasana senja di sebuah masjid yang memeperlihatkan perubahan waktu ke malam hari. Adegan Dea melakukan ibadah shalat magrib menjelaskan bahwa seorang tukang dendang masih taat dalam menjalankan kepercayaannya dalam beragama.

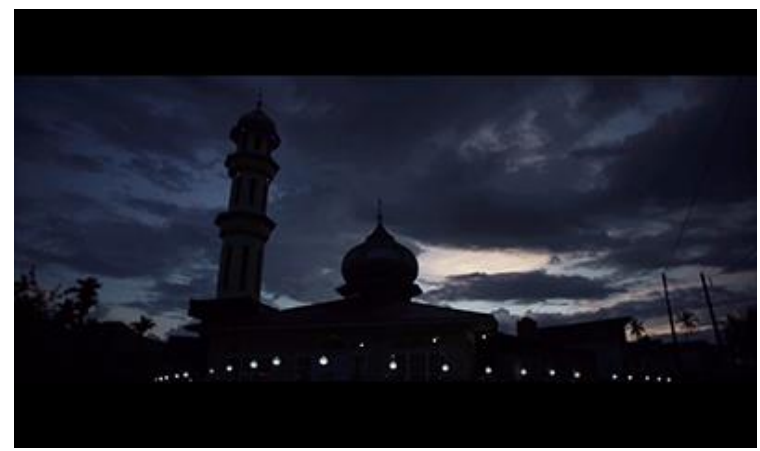

Gambar 6. Scene 7 (Screenshot Film Bagurau)

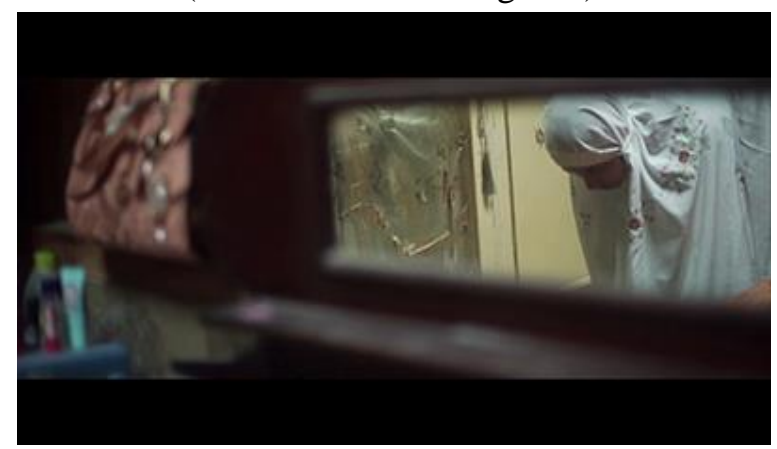

Gambar 7. Scene 8 (Screenshot Film Bagurau)
Suasana Kota Payakumbuh malam hari menjadi awal dari aktifitas para pendukung pertunjukan Bagurau. Dimulai dari pasangan suami istri Tukang saluang dan Tukang dendang melakukan perjalanan Hal| 65 menuju tempat pertunjukan Bagurau. Adegan ini adalah sebuah perbandingan karakter seorang Tukang dendang yang sudah memiliki keluarga. Dilanjutkan dengan beberapa orang crew mempersiapkan lokasi pertunjukan.
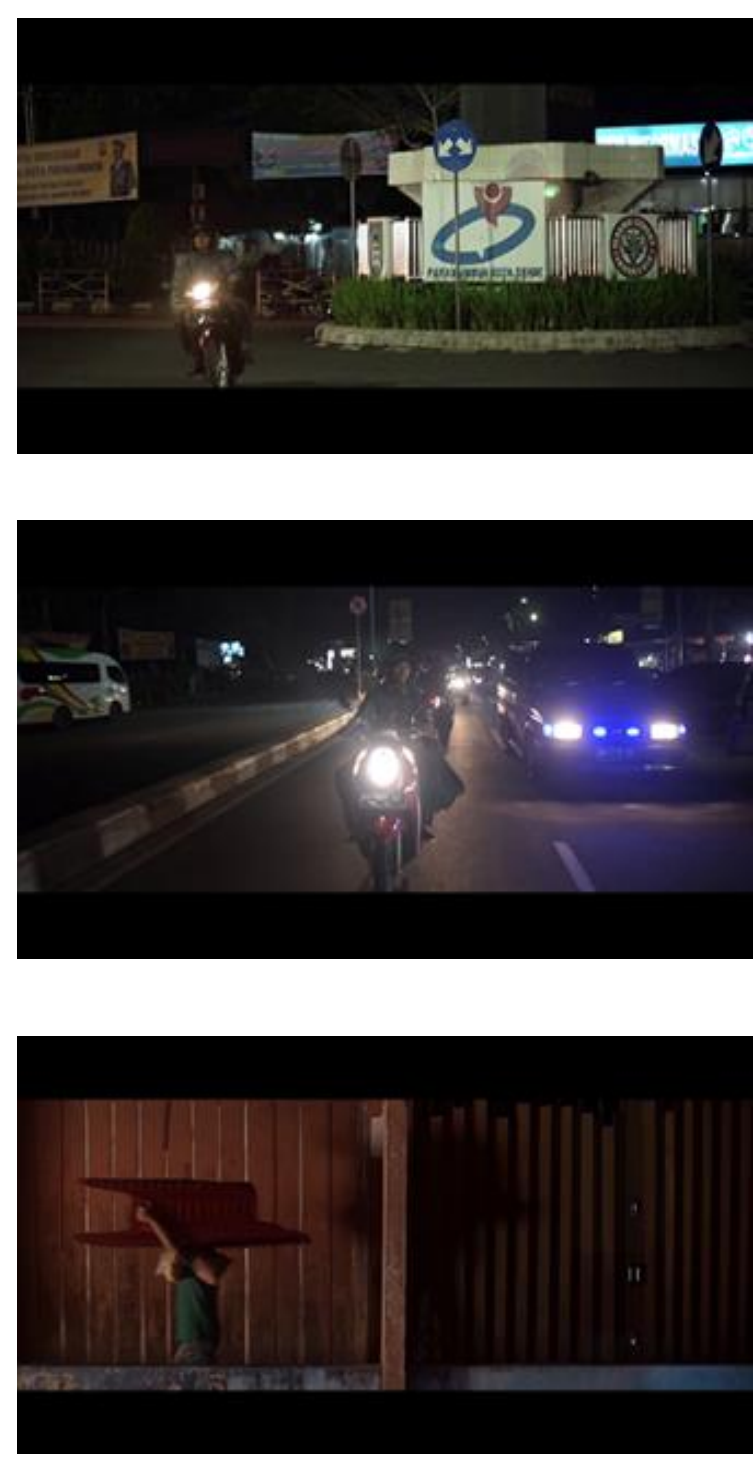


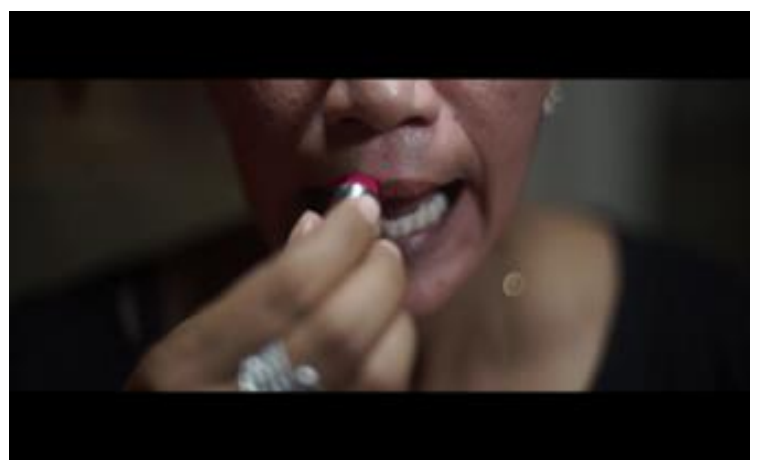

Gambar 8. Scene 9-12

(Screenshot Film Bagurau)

Profesi seorang Tukang Dendang yang identik dengan memakai pamanih (jimat) digambarkan pada adegan Dea memasang rias dan mengenakan baju dimana tampak sebuah jimat terpasang dipinggangnya.

Pandangan positif masyarakat terhadap citra seorang Tukang dendang diperihatkan pada adegan pasangan Pak Haji dan Ibu Haji yang memberi tumpangan kepada Dea menuju tempat pertunjukan Bagurau. Sedangkan pandangan negatif dari masyarakat digambarkan dari tokoh Ibu penjaga warung di tempat Bagurau yang melihat Dea diantar dengan sebuah mobil. Tokoh Rani pada film ini memiliki peran penting dalam meluruskan pandangan buruk masyarakat terhadap Dea.

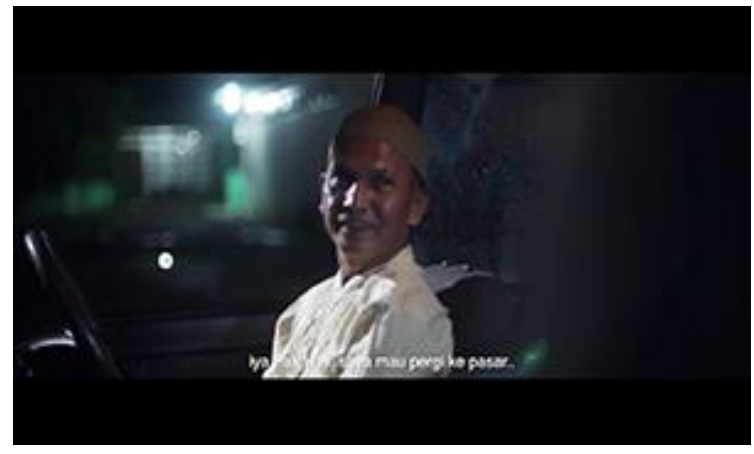

Hal| 66

Gambar 9. Scene 14

(Screenshot Film Bagurau)

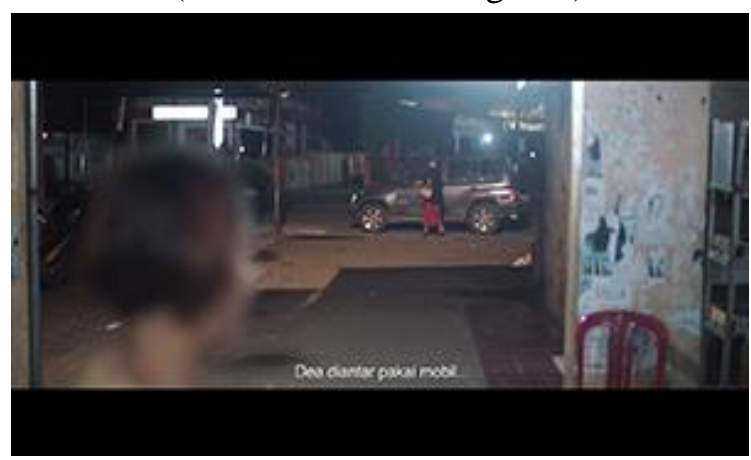

Gambar 10. Scene 17

(Screenshot Film Bagurau)

Eksistensi seorang Buyung dalam mencapai keinginannya mendapatkan hati Dea dijelaskan pada adegan Buyung berdandan didepan cermin. Ketidakharmonisan keluarga Buyung pun terlihat dari Istrinya (Lisa) yang gelisah memperhatikan sikap suaminya. 


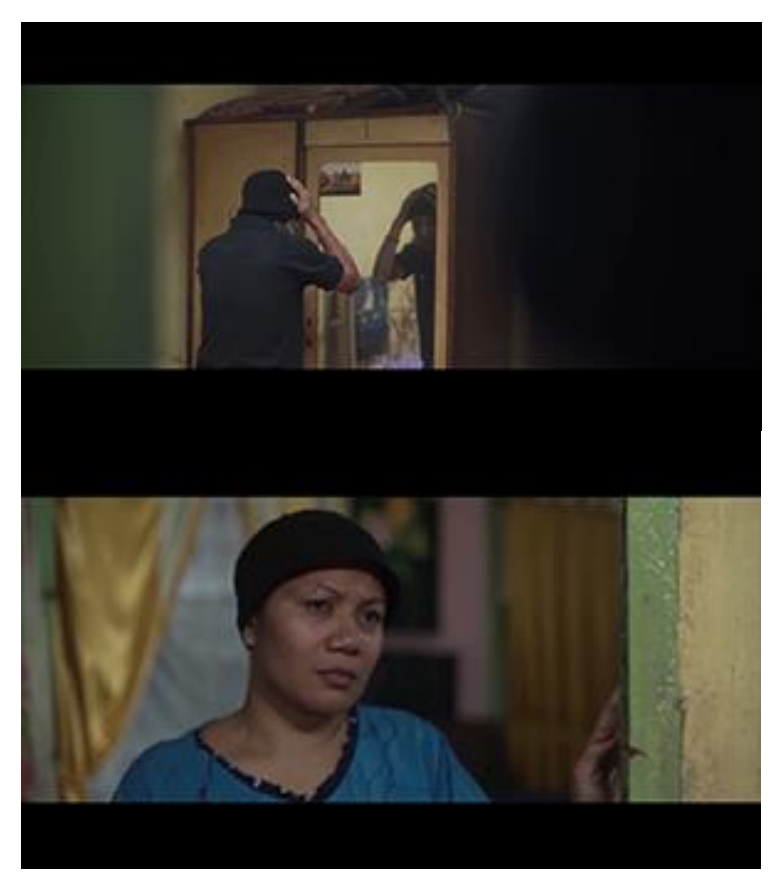

Gambar 11. Scene 16

(Screenshot Film Bagurau)

Sebagai seorang sahabat, karakter tokoh Rani dibentuk menjadi penengah dan pemberi solusi dalam konflik-konflik yang dihadapi oleh Dea. Menepis pandangan buruk orang-orang serta memberikan nasehat kepada Dea.

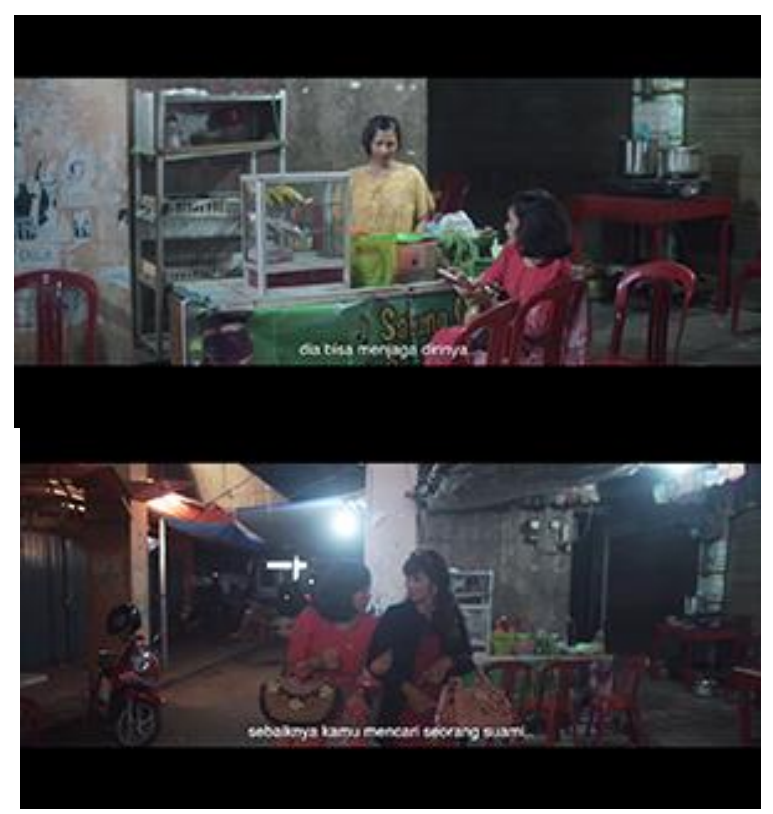

Gambar 12. Scene 17-18

(Screenshot Film Bagurau)
Perjuangan Dea untuk menjadi perempuan Minangkabau yang berlandaskan falsafah adat sebagai limpapeh rumah nan gadang ditekankan pada sikap Dea yang menepis pandangan Hal| 67 buruk tentang dirinya dengan terus menjalani profesinya sebagai Tukang Dendang walaupun banyak godaan yang terus datang menghampirinya seperti pada adegan Buyung memberi tawaran mengantarkan pulang hingga pembelaan saat dirinya diserang oleh Upik yang mana adalah Istri dari Adi yang salah paham terhadap dirinya.

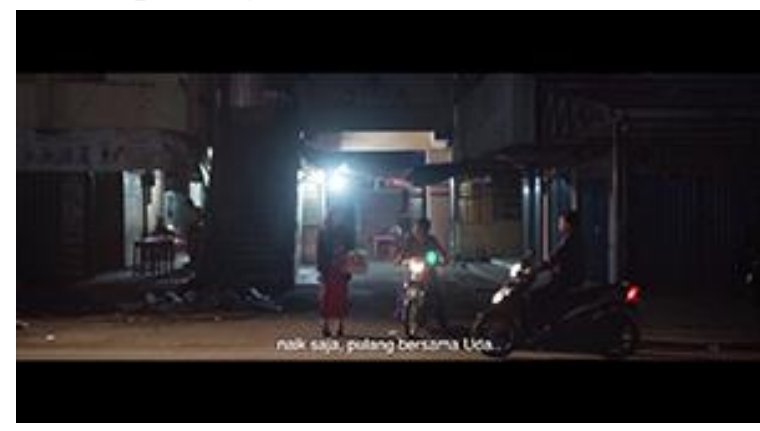

Gambar 13. Scene 22

(Screenshot Film Bagurau)

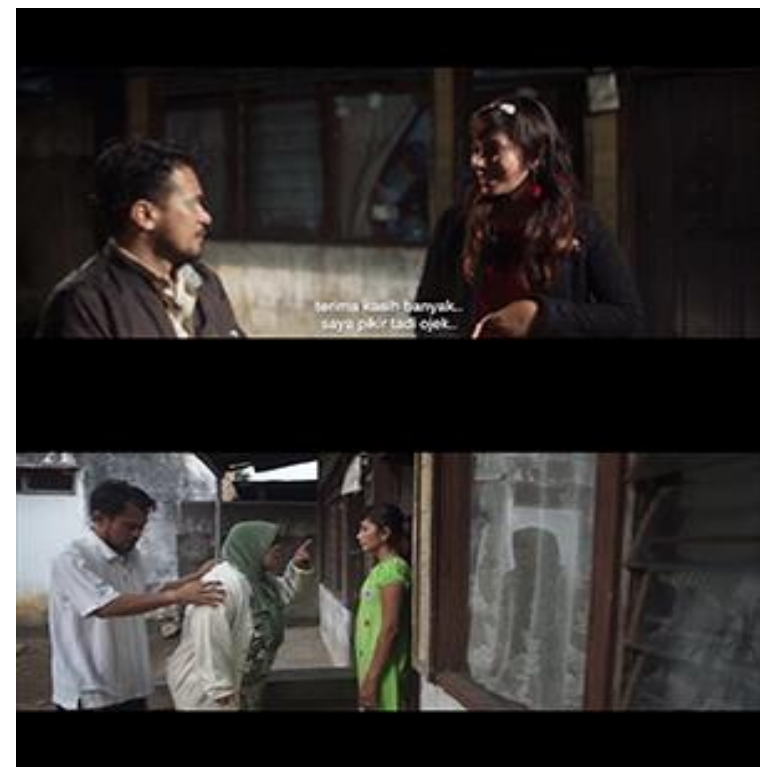

Gambar 14. Scene 24-25

(Screenshot Film Bagurau) 
6. INT. KAMAR MANDI. SORE. H-2 CAST. DEA

SUARA AIR TERDENGAR DARI SUDUT KAMAR MANDI, TAMPAK DEA KELUAR DARI KAMAR MANDI MENGENAKAN HANDUK BERJALAN MENUJU MEJA RIAS. DEA DUDUK DIDEPAN CERMIN LALU MENGAMBIL BEDAK DAN MENGUSAPKAN SPOON BEDAK KE WAJAHNYA.

\section{EXT. MASJID. MALAM. H-2} FOOTAGE

MASJID

8. INT.KAMAR.MALAM. H-2 CAST. DEA

DEA SEDANG MENUNAIKAN IBADAH SHALAT

9. EXT. PASAR. MALAM. H-2 FOOTAGE

SUASANA PASAR KOTA PAYAKUMBUH PADA MALAM HARI PUKUL 19.00 WIB DENGAN KERAMAIAN MOBIL LALULALANG DAN ORANG-ORANG YANG MELAKUKAN AKTIVITASNYA MASINGMASING.

10. EXT. JALAN RAYA. MALAM. H-2 CAST. HARDI, MIRDA

HARDI SEORANG PEMAIN SALUANG SEDANG MENGENDARAI MOTOR DENGAN MEMBONCENG MIRDA MENUJU PASAR TEMPAT ACARA BAGURAU AKAN DILANGSUNGKAN.

\section{EXT. PASAR. MALAM. H-2} CAST. AGUIH

AGUIH BERJALAN DI LORONG TOKO MENGGENDONG TUMPUKAN KURSI.

12. INT. KAMAR. MALAM. H-2

CAST. DEA

DEA SEDANG MEMASANG LIPSTIK MERAH DI BIBIRNYA, DAN MENGUSAPKAN PENSIL ALIS. KEMUDIAN MEMBUKA LEMARI DAN MENGAMBIL SEBUAH PAKAIAN LALU MEMASANGNYA. TERLIHAT SEBUAH JIMAT TERPASANG MELINGKAR DI BAGIAN PINGGANGNYA.
13. EXT. PASAR. MALAM. H-2 CAST. AGUIH, TUKANG ORGEN

PERSIAPAN PERTUNJUKAN BAGURAU

14. EXT. PINGGIR JALAN RUMAH DEA. MALAM. H-2 CAST. DEA, PAK HAJI, BUK HAJI

DEA SEDANG MENUNGGU OJEK DI PINGGIR JALAN DEKAT RUMAHNYA. SEBUAH MOBIL BERHENTI, PAK HAJI TAMPAK SENDIRIAN DI DALAM MOBIL.

\section{PAK HAJI}

"PAI KAPASA DEA..? LAH SAMO SE WAK, APAK KAMAANTAAN GALEH LO KA KADAI..”

DEA

"NDAK USAHLAH PAK HAJI, AMBO JO OJEK SE LAH.."

PAK HAJI

"NDAK BAA GAI DOH, DIBALAKANG ADO IBUK NYO..SADANG MAMACIKKAN GALEH SUPAYO NDK JATUAH.." (MENUNJUK KE BELAKANG)

IBU HAJI

"PEK LAH DEA..DUDUAK SE LAH DIMUKO.

DEA

“EH BUK HAJI..JADIH BUK..

DEA MENAIKI MOBIL PAK HAJI DAN DUDUK DIBANGKU DEPAN.

15. EXT. PASAR. MALAM. H-2 CAST. RANI, SAMSIR, ETEK ETI, HARDI, MIRDA

RANI DATANG DI LOKASI ACARA DIANTAR OLEH SEORANG PEMUDA, LALU BERJALAN MENUJU WARUNG TEK ETI.

TEK ETI

(MENARUH DAGANGAN)

"SIA LO LAI TU RAN..?

RANI MENGELUARKAN CERMIN DARI DALAM TASNYA LALU MEMASANG BEDAK.

\section{RANI}

"CALON TEK...KOK KA LAI LO EH.."

NAN KAPATANG-PATANG RUMIK DEN

DEKNYO TEK, SADO NDAK BULIAH.. 
BAGURAU LO KA DILARANGNYO DEN..

TEK ETI

(TERTAWA)

"YO ITU NYO RAN..MANCARI NAN SUAI TU NAN LENO WAK DEKNYO.."

16. INT. KAMAR BUYUNG. MALAM. DAY 2 CAST. BUYUNG, LISA

BUYUNG TERLIHAT MENYISIR RAMBUTNYA DI DEPAN CERMIN KEMUDIAN MENYEMPROTKAN PARFUME KE SELURUH TUBUHNYA, TAMPAK BAYANGAN ISTRINYA (LISA) YANG GELISAH DARI LUAR KAMAR.

17. EXT. PASAR. MALAM. H-2

CAST. RANI, HARDI, ETEK ETI, SAMSIR, MIRDA

TEK ETI SEDANG MENARUH KERTAS DAN PENA DI MEJA-MEJA PENONTON. KEMUDIAN MEMPERHATIKAN DEA TURUN DARI SEBUAH MOBIL. DEA TURUN DARI MOBIL PAK HAJI DAN BERJALAN MENUJU WARUNG TEK ETI. DI SANA ADA RANI YANG SEDANG BERMAIN HANDPHONE SEMBARI MEROKOK.

TEK ETI

(MEMANGGIL RANI)

"RAN,CALIAKLAH SI DEA TU,LAH JO OTO NYO KA PASA KINI

RANI

"BIA SE LAH TEK, NDAK URUSAN WAK T DOH..DEA TU TAU LO JO NAN NDK PATUIK MAH.

DEA SAMPAI DI WARUNG TEK ETI

TEK ETI

"NAIAK RAZAKI KINI MAH DEA..

\section{DEA}

"PAK HAJI AKBAR JO BININYO TU MAH TEK..DEK LAI SAARAH TU NUMPANG SE AMBO LAI.

TEK ETI

"OOOWW..SANGKO ETEK KOK CALON LO TADI TU.."

DEA TERSENYUM MENANGGAPI PERKATAAN TEK ETI KEMUDIAN
MENGELUARKAN SPON BEDAK DAN MERAPIKAN DANDANANNYA.

HARDI DAN MIRDA DATANG DENGAN MOTOR KEMUDIAN DUDUK DIWARUNG TEK ETI. HARDI MEMESAN SEGELAS KOPI. MIRDA MENGELUARKAN BEDAK DARI DALAM TASNYA, BERCERMIN DAN JUGA MERAPIKAN DANDANANNYA.

18. EXT. PASAR WARUNG. MALAM. H-2

CAST. DEA, RANI, HARDI, MIRDA, JANANG

JANANG DATANG BERJALAN KE WARUNG TEK ETI.

$$
\begin{gathered}
\text { JANANG } \\
\text { (MEMINJAM KOREK API KE HARDI) } \\
\text { "MINTAK API DA HARDI.. } \\
\text { (MENOLEH KE TUKANG DENDANG) } \\
\text { "BAA.? MULAI KITO LAI..? }
\end{gathered}
$$

JANANG MENGAJAK DEA, RANI, HARDI, SAMSIR, MIRDA MENUJU PENTAS BAGURAU. MEREKA SEMUA BERJALAN KEATAS PANGGUNG, KEMUDIAN RANI MEMANGGIL DEA.

\section{RANI}

"DEA, CARILAH LAKI LAI, NDAK SANANG LO TALINGO DEN MANDANGA URANGURANG MAMPAGUNJIANGAN KAU DOH.."

\section{DEA}

(PASRAH)

"BIA SE LAH URANG-URANG TU RAN, NAN DEN KAN NDAK ADO MANGAMANGA DOH.

KAU MANGECEKKAN DEN SE NAN

PANDAI, KAU CARILAH LO LAH LAKI LAI..

LAH BALUMUIK TU A..

RANI TERTAWA MENDENGAR PERKATAAN DEA. MEREKA BERDUA MENAIKI PENTAS, SEMENTARA ITU BUYUANG DATANG LALU MEMARKIR MOTORNYA, BUYUANG MEMESAN KOPI KEPADA TEK ETI DAN BERJALAN KEMEJA YANG BERADA DIPOSISI DEPAN DEKAT DENGAN PENTAS.

19. EXT. PASAR. MALAM. H-2 CAST. DEA, RANI, HARDI, SAMSIR, MIRDA, JANANG, TONI, BUYUNG

JANANG YANG SEBAGAI PEMBAWA ACARA LANGSUNG MEMBUKA ACARA DENGAN PETATAH-PETITIH MINANGKABAU. BEBERAPA PENONTON 
SUDAH MULAI BERDATANGAN SATU PERSATU.

JANANG

"BAIAKLAH.. KABAKEH MAMAK SARATO DUNSANAK YANG HADIR MALAM NAN KO, KOK KETEK NDAK DISABUIKKAN NAMO, KOK GADANG NDAK DIPANGGIAKAN GALA. KITO AGIAH UNTUAK DEA MAMBUKAK ACARA MALAM KO.. SALAMAIK BAGURAU SAMALAM SUNTUAK.."

DEA MEMULAINYA DENGAN DENDANG PEMBUKA YANG BERJUDUL SINGGALANG.

DEA

(DENDANG)

“CUPAK PANUAH GANTANG BALANJUANG, KA CUPAK URANG KA TIGO LUHAK, JATUAH KA ALAM MINANGKABAU, HANYO SAMBAH SALAM DIANJUANG, RILA JO MAAF KAMI MINTAK...",

TONI DATANG DENGAN DUA ORANG TEMANNYA KEMUDIAN DUDUK DI KURSI SUDUT. BUYUNG MELIHAT KEARAH TONI YANG MEMBALAS DENGAN SENYUMAN. SEMENTARA ITU ADI JUGA DATANG LALU DUDUK DIWARUNG TEK ETI MEMESAN SEGELAS KOPI SAMBIL MENYAKSIKAN BAGURAU. BUYUANG BERJALAN KEARAH PENTAS MEMBISIKKAN PESANAN DENDANG KEPADA JANANG.

JANANG

"SEBUAH PASAN DARI UDA BUYUANG, "BAA DEK ACOK BAMANUANG DEA? MANGAMEK GAI LAH AGAK

SAKETEK..BULIAH SANANG PULO HATI UDA MANCALIAKNYO.."

BAIAKLAH DEA...SAMPAIANLAH

PERMINTAAN UDA BUYUNG TU AGAK SAKETEK..."

DENGAN BERAT HATI YANG TERGAMBARKAN DARI WAJAH DEA UNTUKMELANTUNTAKAN DENDANG PERMINTAAN BUYUANG. ADI MEMPERHATIKAN DEA DARI JAUH.

20. EXT. PASAR. SUBUH. H-3 CAST. DEA, RANI, HARDI, SAMSIR, MIRDA, JANANG, TONI, BUYUNG

ADZAN SUBUH BERKUMANDANG, BEBERAPA WARGA TAMPAK MEMAKAI MUKENA DAN PECI BERJALAN MENUJU MASJID. ADI MEMBAYAR BELANJAANNYA KEPADA TEK ETI DAN
BERLALU PERGI. JANANG MENUTUP PAGURAUAN.

21. INT. MASJID. SUBUH. H-3 FOOTAGE

ORANG-ORANG TAMPAK HIKMAT BERIBADAH.

22. EXT. PASAR GANG. SUBUH. H-3

CAST. DEA, RANI, HARDI, MIRDA, JANANG, BUYUNG, ADI, TEMAN RANI

DEA BERJALAN SENDIRIAN DISEBUAH GANG MENUJU JALAN RAYA. HARDI DAN MIRDA SERTA JANANG LEWAT DENGAN MOTOR MENDAHULUI DEA. SEDANGKAN RANI TAMPAK DIANTAR OLEH SALAH SEORANG PENONTON. BUYUNG DATANG MENGHAMPIRI DEA DARI BELAKANG.

$$
\begin{gathered}
\text { BUYUNG } \\
\text { "NAIAKLAH DEA..BIA UDA ANTAAN } \\
\text { PULANG.." } \\
\text { DEA } \\
\text { "NDAK USAH LAH DA, BIA AMBO NAIAK } \\
\text { OJEK SAJO.." } \\
\text { BUYUNG } \\
\text { "NDAK BAA GAI DOH DEA..PEK LAH.. } \\
\text { (MENGIRINGI DEA BERJALAN) }
\end{gathered}
$$

\section{BUYUNG}

DEA TIDAK MENGHIRAUKAN TAWARAN BUYUNG DAN TERUS BERJALAN, SEDANGKAN BUYUNG MASIH MENGIKUTINYA. SESAMPAI DI DEPAN JALAN RAYA, ADI DATANG MENAWARKAN OJEK KE DEA.

$$
\text { ADI }
$$

"OJEK NI..?"

DEA NAIK KE MOTOR ADI DAN BUYUNG KECEWA MELIHATNYA PERGI. TONI DATANG DARI BELAKANG BUYUNG MENYAPA DAN MENDAHULUINYA.

23. INT. RUMAH BUYUNG. SUBUH. H-3 CAST. BUYUNG, LISA

BUYUNG MEMBUKA PINTU RUMAH, DIDEPANNYA LISA SEDANG DUDUK MENUNGGU KEDATANGANNYA

\section{LISA}

"SAMPAI BILO UDA KAMODE IKO..? PULANG SUBUAH, JAGO SIANG..BILO UDA KA KARAJO..? 
BUYUNG TIDAK MENGHIRAUKAN PERKATAAN LISA DAN TERUS BERJALAN KEDALAM KAMAR. LISA MEMANGGILMANGGIL BUYUNG DAN MENANGIS.

24. EXT. RUMAH DEA. PAGI. H-3 CAST. DEA, ADI. ERA

ADI MEMBERHENTIKAN MOTOR DI DEPAN RUMAH DEA, DEA TURUN DAN MENGELUARKAN UANG UNTUK MEMBAYAR OJEK, ADI MENOLAK PEMBERIAN DEA.

ADI

"PACIK SE LAH DEA, UDA KA PULANG JUO NYO, KEBETULAN ARAH WAK SAMO..

DEA

"NDEH DA..TARIMO KASIH BANYAK YO DA, SANGKO AMBO TADI UDA OJEK.

\section{ADI}

IYO SAMO-SAMO DEA..UDA BALIAK DULU DIH..

ADI PERGI, DEA MASUK KEDALAM RUMAH. ERA TETANGGA DEA MENGINTIP DARI JENDELA RUMAHNYA.

\section{INT. RUMAH DEA. PAGI. H-3}

CAST. DEA, UPIK, ADI, ERA

PINTU RUMAH DEA DIGEDOR OLEH UPIK YANG ADALAH ISTRI DARI ADI. DEA TERBANGUN DARI TIDURNYA DAN BERJALAN KELUAR.

ADI DATANG DENGAN SEPEDA MOTOR MENJEMPUT ISTRINYA YANG MASIH MENGGEDOR SAMBIL BERTERIAK DIDEPAN PINTU RUMAH DEA.

$$
\text { ADI }
$$

(TURUN DARI MOTOR DAN MENDEKATI UPIK)

"PIAK..MANGA KAU KO..?"

UPIK

"ANTOKLAH DA, DEN NIO MAAJAAN ALUA JO PATUIK KA TUKANG DENDANG KO A.."

\section{ADI}

"LAH DEN JALEHAN DI RUMAH TADI.. ADEN NAN SALAH.. INYO NDAK TAU APO-APO TU DOH.."

DEA MENGINTIP UPIK DAN ADI YANG SEDANG BERTENGKAR DIDEPAN RUMAHNYA.

\section{UPIK}

UDA BELA PAJA KO YO?

(MENGGEDOR PINTU)

"OII..KALUA LAH KAU.."

ADI

(MENARIK UPIK)

"PIAK, DI RUMAH WAK BAHAS

Hal 71

DEA MEMBUKA PINTU, LALU MENATAP MATA UPIK. UPIK MENDEKATI WAJAH DEA.

UPIK

"KAU IDUIK DISIKO HARUS BATARATIK.."

DEA

"ADEN TAU ALUA JO PATUIK PUNYO RASO JO PARESO

JAN SADOALANYO BASABUIK DEN HANYO BAKARAJO

\section{UPIK}

"KARAJO KAU MAAMBIAK LAKI URANG, PULANG SUBUAH, PADUSI SARUPO APO NAN MODE TU..?

DEA

"PADUSI NAN BARUSAHO MAMBANGUN LIMPAPEH RUMAH NAN GADANG JO USAHO SURANG..PAGURAUAN TAMPEK KARAJO DEN MANJADI ANAK DENDANG, INDAK MARABUIK LAKI URANG.

UPIK

"MAILAK JO KAU LAE PANT.."

UPIK YANG INGIN MENAMPAR DEA LANGSUNG DI TAHAN OLEH ADI. ERA TETANGGA DEA KELUAR MELIHAT KEJADIAN TERSEBUT. ADI, UPIK DAN DEA TERKEJUT KEDATANGAN ERA DENGAN WAJAH MARAH.

ERA

"MANGA KO..?

KAU SIA..? TOLONG BATARATIK DISIKO STEK.

UPIK

"IYO..MAAF NI..WAK ADO MASALAH JO INYO NYO NI.."

ERA

"HOI.. LAKI KAU KO SE NAN KA DI JAGO.. JAN MANTANG-MANTANG INYO ANAK DENDANG, BURUAK SE DEK KAU SADONYO..

ADEN SE NAN DAKEK NDAK PERNAH TAGADUAH DOH.." 
UPIK DAN ADI TERDIAM. MEREKA PERGI MENINGGALKAN RUMAH DEA.

\section{Babak III}

Babak terakhir dalam film ini merumuskan bahwa perjuangan yang dilakukan Dea tidak akan menemukan titik akhir jika tetap masih sendiri dan tidak mencari seorang suami. Nasihat-nasihat yang diberikan oleh Rani menjadi renungan Dea untuk menentukan sikap dan pilihan.

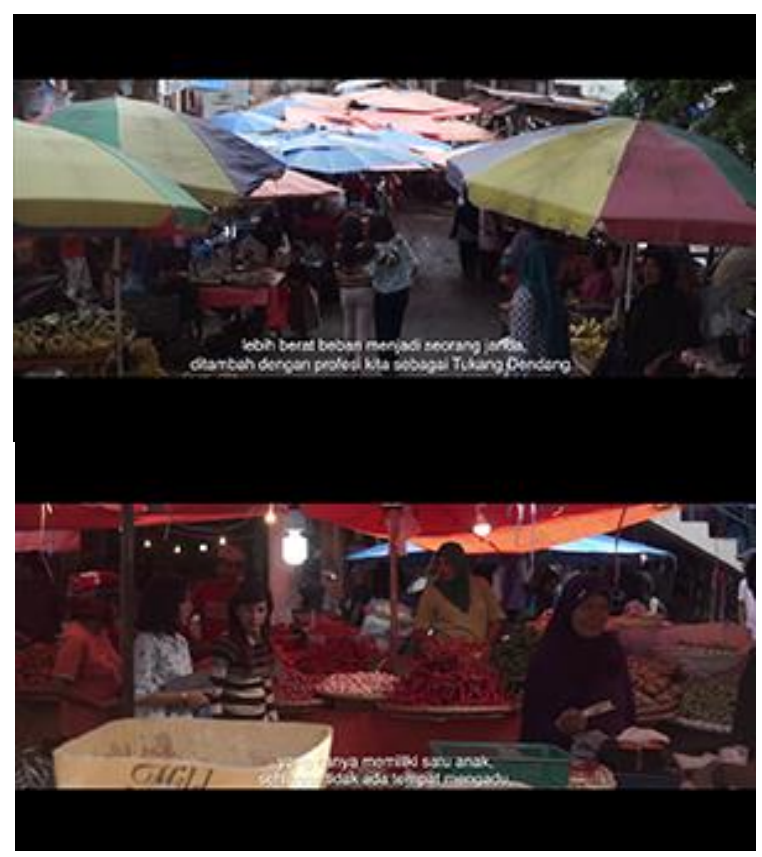

Gambar 15. Scene 26

(Screenshot Film Bagurau)

Dea dan Buyung akhirnya menikah, setelah buyung bercerai dengan Lisa. Siklus yang terjadi pada Dea bertukar kepada Lisa mantan istri Buyung yang kembali menjalani profesinya sebagai Tukang Dendang. Serta sebuah adegan anak Lisa yang bersamanya di atas pentas Bagurau menjadi sajian akhir dalam film ini. Adegan ini menjelaskan bahwa anak Lisa adalah regenerasi Tukang dendang, yang mana pada realitasnya profesi sebagai Tukang dendang akan turun kepada anak dari seorang Tukang dendang tersebut.
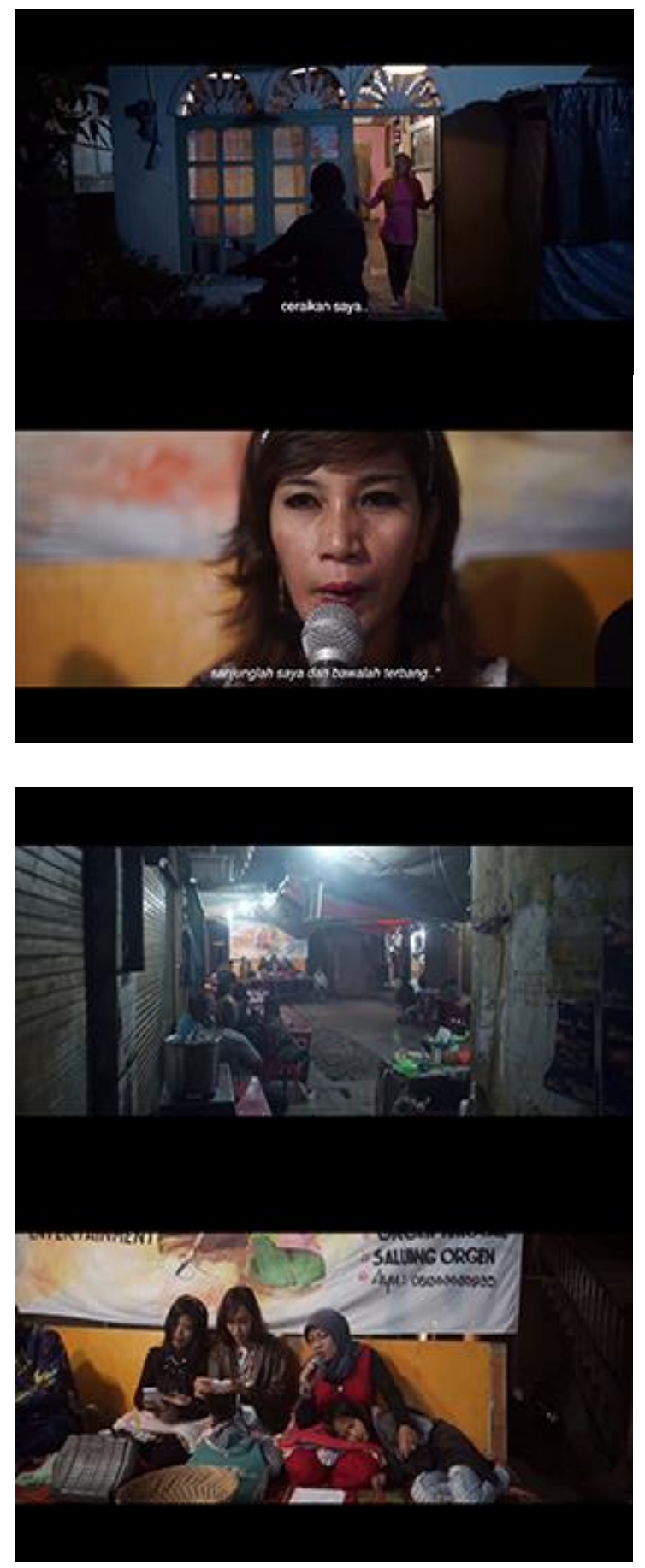

Gambar 16. Scene 28-30 (Screenshot Film Bagurau) 


\section{EXT. PASAR. SIANG. H-3}

CAST. DEA, RANI, LISA

RANI DAN DEA SEDANG BELANJA DIPASAR. LISA MEMPERHATIKAN MEREKA DARI KEJAUHAN.

INSERT. LAKI-LAKI PEDAGANG DAN PENGUNJUNG PASAR, IBU DAN ANAKNYA, ANAK-ANAK BERSERAGAM SEKOLAH.

RANI (VO)

"SARUPO JO NAN DEN KECEKKAN KAPATANG, UBEKNYO KAU MEMANG HARUS MANCARI LAKI LAI TU.. LABIAH BAREK MANJADI JANDO KO MAH, TAMBAH LO WAK TUKANG DENDANG.."

DEA (VO)

"DEN LAI BAPIKIA BANTUAK TU MAH RAN..CARI PITIH SURANG, ABIHAN SURANG..UNTUAK SIA DEN BAJUANG MANJADI LIMPAPEH RUMAH NAN GADANG JADINYO, KALAU KA IDUIK SURANG JUO DAN INDAK MAMIKIAAN PANARUIH DEN..

\section{RANI}

"LAI TAU KAU MAH YO.. TAPI DEN YAKIN KAU BISA MANJADI TUKANG DENDANG SABAGAI LIMPAPEH RUMAH NAN GADANG MAH DEA..HAHAA...

CIEK LAI, SASUDAH BALAKI BUEK ANAK BANYAK-BANYAK JAN TIRU LO AMAK JO ENEK KAU TU, NDAK ADO TAMPEK MANGADU, TASESO ANAK JO CUCU BANTUAK KAU KINI KO A.."

\section{EXT. PASAR. MALAM. H-3}

CAST. RANI, JANANG, HARDI, MIRDA, TEK ETI, ADI

$\begin{array}{llrr}\text { SEMUA PENDUKUNG } & \text { PERTUNJUKAN } \\ \text { BAGURAU } & \text { SEDANG } & \text { MENUNGGU } \\ \text { KEDATANGAN DEA. JANANG DAN RANI } & \text { DANAN } \\ \text { MENGOBROL } & \text { DISALAH } & \text { SATU } & \text { MEJA } \\ \text { DEKAT PENTAS, HARDI } & \text { DAN } & \text { MIRDA } \\ \text { DUDUK DI } & \text { WARUNG } & \text { TEK } & \text { ETI, } \\ \text { SEDANGKAN ADI DUDUK } & \text { DI ATAS } \\ \text { MOTOR DIPARKIRAN. DEA } & \text { DATANG } \\ \text { DENGAN OJEK DAN } & \text { LANGSUNG } \\ \text { DIHAMPIRI ADI. } & & \end{array}$

\section{ADI}

"DEA, UDA NIO MINTA MAAF SOAL NAN TADI PAGI.."
DEA

"IYO DA, NDAK BAA DOH DA"

(BERJALAN)

ADI

"DEA..UDA NIO.."

DEA

Hal| 73

(MENOLEH)

"SALASAIAN SE LAH URUSAN RUMAH

UDA.."

ADI MEMPERHATIKAN DEA BERJALAN MENUJU PENTAS DAN MENOLEH KEARAH JANANG. JANANG MELIHAT ADI BERJALAN KE KURSI SUDUT.

\section{INT. RUMAH BUYUNG. MALAM. H-3} CAST. BUYUNG, LISA

DI DINDING KAMAR TERPAMPANG SEBUAH FOTO LISA SEWAKTU MENJADI SEORANG TUKANG DENDANG. DIDEDEPAN CERMIN BUYUNG SEDANG MENGENAKAN BAJU, LISA MASUK KEDALAM KAMAR KEMUDIAN DUDUK DITEPI KASUR MEMPERHATIKAN BUYUNG

\section{LISA}

“DA..AMBO MANDANGA UDA RIBUIK DI PAGURAUAN.. IYO TU DA..?"

\section{BUYUNG}

"IYO.. BAA TU..?

(BERJALAN KE CERMIN, MENYISIR RAMBUT, MEMAKAI PEWANGI)

LISA

"ADO SANGKUIK PAUIKNYO JO TUKANG DENDANG DA..?"

BUYUNG BERJALAN KELUAR KAMAR TANPA MENJAWAB PERTANYAAN LISA. LISA PUN MENYUSUL BUYUNG.

\section{LISA}

"AMBO TAU NYO DA..DULU UDA BANTUAK IKO LO WAKATU MANGAJANGAJA AMBO NAK..?"

BUYUNG MENGABAIKAN LISA DAN BERJALAN KELUAR RUMAH.

LISA

(MEMANGGIL BUYUNG)

"DA..KALAU ITU BATUA..CARAIKAN AMBO DA..!"

BUYUNG MELIHAT KEARAH LISA DAN MENGHIDUPKAN MOTORNYA 
KEMUDIAN BERLALU PERGI. LISA BERDIRI DI DEPAN PINTU MELIHAT BUYUNG PERGI.

\section{INT. PASAR. MALAM. H-3}

CAST. DEA, SAMSIR, RANI, HARDI, MIRDA, ADI, BUYUNG, TONI

ACARA BAGURAU
BERLANGSUNG. BUYUNG
DENGANG
DENGAN SEPEDA MOTORNYA DAN
LANGSUNG BERJALAN KE PENTAS
MEMESAN DENDANG KEPADA JANANG.

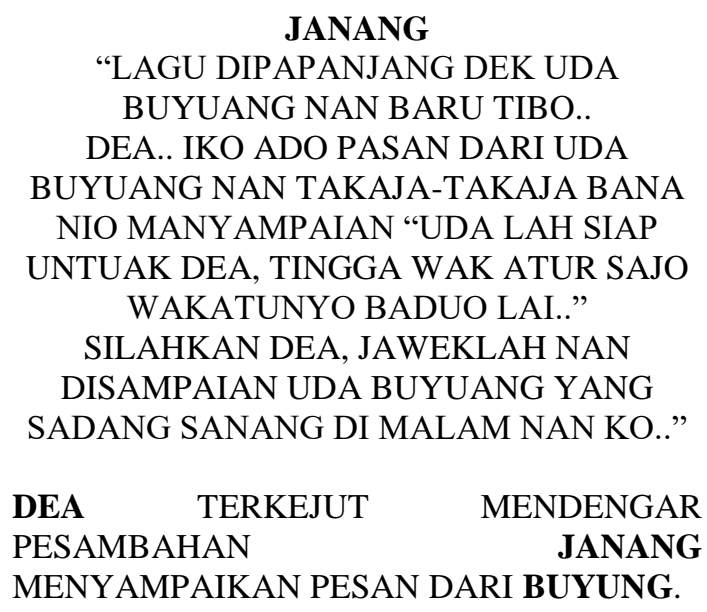

FLASBACK (SCENE 2, 4, 6, 26)

DEA MEMULAI DENDANGNYA DENGAN KERAGUAN.

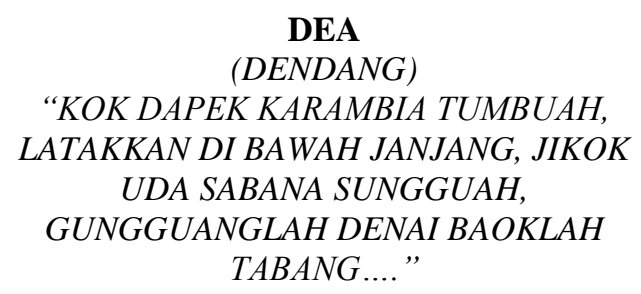

DEA TERSENYUM LALU MELIRIK KEARAH BUYUNG. SEMUA PENONTON TERTAWA DAN BUYUNG KEGIRANGAN MENDENGARKAN LANTUNAN DEA YANG MERESPON BAIK KEINGINANNYA. SEDANGKAN ADI YANG MENDENGAR PANTUN DEA TERSEBUT LANGSUNG MENINGGALKAN LOKASI BAGURAU DENGAN MOTORNYA.

SUASANA BAGURAU MENJADI SEMAKIN MERIAH.

FADE OUT

FADE IN
30. INT. PASAR. MALAM. H-4

CAST. LISA, SAMSIR, RANI, HARDI, MIRDA, JANANG, ANAK LISA

PERSONIL KELOMPOK BAGURAU PADA MALAM ITU TAMPAK BERBEDA DARI BIASANYA. POSISI TUKANG DENDANG Hal| 74 YANG BIASANYA DIISI OLEH DEA DIGANTIKAN OLEH LISA. ANAK LISA TERTIDUR DIDEPANNYA YANG SEDANG MELANTUNKAN SEBUAH DENDANG TENTANG SESEORANG YANG PATAH HATI.

LISA

(DENDANG)

"KA GOLARIA KITO MALAH, MUKASUIK

HATI HANDAK MANONTON, KAMASUAK

DIBALI KACANG GORENG, FILM BAPUTA

LAMPU MATI, BAGALESOH SABALAH SUOK, DISANGKO RUGUIH FILM KUNGFU, KIRONYO URANG BAPACARAN.."

TAMAT

\section{PENUTUP}

Fenomena perempuan yang rela bekerja namun bertentangan dengan adat budaya Minangkabau dalam memandang perempuan. Film yang berangkat dari budaya setempat yaitu perempuan yang berprofesi sebagai Tukang Dendang dilihat dari sistem matrilineal dan falsafah adat Minangkabau limpapeh rumah nan gadang. Pada kenyataannya perempuan Minangkabau adalah mereka yang berkedudukan mulia dan terhormat, tidak perlu bekerja untuk kebutuhan ekonomi, menjauhi sumbang salah dalam hidup bermasyarakat. Adapun sumbang salah menurut adat Minangkabau bagi seorang perempuan adalah ke luar rumah pada malam hari, bergaul dengan laki-laki, 
berpergian dengan laki-laki yang bukan keluarganya. Namun Tukang Dendang yang juga seorang perempuan ke luar dari persoalan kultural tersebut.

Makna dari falsafah ini bisa menyesuaikan dengan keadaan perempuan tersebut. Hal ini berlaku bagi perempuanperempuan yang bekerja sebagai Tukang Dendang. Mereka menjaga rumahnya (rumah ini bisa diartikan sebagai hidupnya sendiri) dengan cara mencari nafkah melalui sebuah pertunjukan Bagurau.

Kondisi tersebut menunjukkan bahwa nilai-nilai adat istiadat mengalami perubahan dan perkembangan sesuai dengan perubahan perkembangan masyarakatnya. Orang Minangkabau mengatakan Adat dipakai baru, baju dipakai usang, maksudnya bahwa adat itu semakin dipakai akan menimbulkan bentuk-bentuk baru. Ungkapan ini juga mengandung makna, bukan hanya kehidupan berdasarkan adat istiadat, tetapi nilai-nilai adat istiadat itupun tumbuh dari kehidupan masyarakatnya. Dalam falsafah adat Minangkabau juga mengungkapkan Sakali aia gadang, sakali tapian baraliah, sakali tahun berganti, sakali musim bakisa (sekali banjir, sekali juga tepian beralih, sekali tahun berganti, sekali musim bertukar), maksudnya perubahan-perubahan zaman akan menyebabkan terjadinya perubahan-perubahan nilai-nilai kehidupan atau adat istiadatnya.
Film Bagurau ini menerapkan unsur cerita memakai format alternatif struktur tiga babak dengan metode muti-plot dari perspektif beberapa tokoh dan metode naratif realistik di mana metode ini Hal| 75 memiliki akhir cerita yang mengambang (open ending). Film ini berkonten lokal namun bisa diterima secara universal, karena permasalahan perempuan ini tidak hanya persoalan perempuan Minangkabau tapi juga terjadi di mana saja. Film ini dikemas sederhana dan mudah difahami agar bisa ditonton oleh semua kalangan.

\section{KEPUSTAKAAN}

Andar Indra Sastra, 2010. "Bagurau Malam Dalam Kemasan Manajemen Konflik di Sumatera Barat". Laporan Penelitian. Sekolah Tinggi Seni Indonesia Padangpanjang.

Esten, Mursal. 1993.Minangkabau: Tradisi dan Perubahan. Bandung: Angkasa.

Erlinda. 1999. "Kehadiran Wanita Dalam Musik Malam (Saluang dan Dendang) di Minangkabau Sumatera Barat". Laporan Penelitian, Akademi Seni Karawitan Indonesia Padangpanjang.

Hakimy, Idrus. 1994. Rangkaian Mustika Adat Basandi Syara' di Minangkabau, Bandung: PT. Remaja Rosda Karya.

Kamus Besar Bahasa Indonesia. 2002.Jakarta: Balai Pustaka, Edisi Ketiga.

Kamus Kecil Istilah Film. 2009.Jakarta: Yayasan Pusat Perfilman H. Usmar Ismail, Edisi Kelima. 
Navis, AA. 1984. Alam Takambang Jadi Guru. Jakarta: Temprin.

Noni Sukmawati, 2003. "Perempuan Dalam Seni Pertunjukan Bagurau. Perubahan Sosial di Minangkabau". Tesis, Universitas Gadjah Mada Yogyakarta.

Pratista, Himawan. 2008.Memahami Film. Yogyakarta: Homerian Pustaka.

Sani, Asrul, 1992. Cara Menilai Sebuah Film. Jakarta: Yayasan Citra.

Sumarno, Marselli. 1996. Dasar-Dasar Apresiasi Film. Jakarta: PT Gramedia Widiasarana Indonesia.

Syafniati, 2014."Pandangan Masyarakat Terhadap Wanita Sebagai
Pendendang Dalam Acara "Bagurau Lapiak" di Payakumbuh". Laporan Penelitian.

\section{Daftar Narasumber}

Yusril, 50 Tahun, (Dosen ISI Hal| 76

Padangpanjang), Agustus 2016

Abdul Rahman, 39 Tahun, (Dosen ISI Padangpanjang) November 2016 Mak Lenggang, 51 Tahun, (Dosen ISI Padangpanjang, Tukang Saluang), Desember 2016

Arnelis, 53 Tahun, (Dosen ISI Padangpanjang, Tukang Dendang) Desember 2016 Dea, 35 Tahun, (Tukang Dendang), Desember 2016 